Nig. J. Pure \& Appl. Sci. Vol. 34 (Issue 2, 2021)
e- ISSN 2756-4045
Life Sciences, Univ. of Ilorin, Nigeria
www.njpas.com.ng

\title{
Immunomodulatory Activity of Aqueous Extract of Polyherbal Formulation on Macrophage Function and Humoral Immune Response against SRBCs in Mice
}

\author{
*Hamid, K. M. ${ }^{1}$, Shehu, A. A. ${ }^{1}$, Kalgo, M. U. ${ }^{1}$, Isiyaku, A. ${ }^{1}$, Alkali, S. ${ }^{1}$, Muhammad, T. ${ }^{1}$, Usman, A. B. ${ }^{1}$, \\ Isah, S. Y. ${ }^{2}$ and Abubakar, N. K. ${ }^{3}$ \\ Page | 3989 \\ ${ }^{1}$ Department of Immunology, School of Medical Laboratory Sciences, Usmanu Danfodiyo University, P.M.B. 2346, \\ Sokoto, Nigeria \\ ${ }^{2}$ Department of Medical Laboratory Science, Faculty of Allied Health Sciences, Bayero University. P.M.B. 3011, \\ Kano, Nigeria \\ ${ }^{3}$ Department of Health Services, Federal University Birnin Kebbi, P.M.B. 1157, Kebbi, Nigeria
}

Date Received: 06-01-2021

Date Accepted: 28-07-2021

DOI: https://doi.org/10.48198/NJPAS/21.A01

\begin{abstract}
Several herbal formulation were not properly documented due to poor scientific data as well as poor standard regulation in preparation and marketing. The study evaluate the effect of aqueous extract of Polyherbal formulation on Macrophages' phagocytic function and Humoral immune response in Mice A total of Sixteen 16 Mice was used. Group I received normal saline, Group II-IV received $500 \mathrm{mg}, 1000 \mathrm{mg}$, and $1500 \mathrm{mg}$ of Polyherbal formulation respectively for 21 days each. The animals were sensitized and challenged with Sheep red blood cells at day $14^{\text {th }}$ and $19^{\text {th }}$ of the treatment respectively. On day $21^{\text {st }}$ all the animals were injected with $0.1 \mathrm{ml}$ Indian ink for carbon clearance assay and blood sample was collected at 1 minute and 15 minutes of the injection. The phagocytic function of Macrophages and humoral immune response were determined spectrophotometrically and Hemagglutination assay respectively. The results show that the highest carbonic particle clearances index $(\mathrm{K})$ median score $($ Median=0.0228), Macrophage phagocytose index $(\alpha)$ median score (Median=3.249), organ weight index $(\mathrm{g} / 100 \mathrm{~g})$ mean score $(\mathrm{M}=0.06633)$ and Hemagglutination antibody titre median score (Median=32.00) was recorded by Group IV when compared with other groups. The carbonic particle clearance $(\mathrm{K})(\mathrm{p}=0.02)$, phagocytic index of Macrophage $(\alpha)(\mathrm{p}=0.03)$, and organ weight index $(\mathrm{g} / 100 \mathrm{~g})$ $(\mathrm{p}<0.0001)$ significantly increase with increase in the Polyherbal formulation concentration. Hemagglutination antibody titre against Sheep red blood cells $(\mathrm{p}=0.02)$ also significantly increased. The extract has potential immunostimulatory activity on both Macrophages' phagocytic function and humoral immune response in mice thus could be useful in improving immune responses.
\end{abstract}

Keywords: Hemagglutination, Humoral, Immunity, Macrophages, Mice, Phagocytes

Corresponding Author: Hamid, K. M.

Department of Immunology, School of Medical Laboratory Sciences, Usmanu Danfodiyo University, P.M.B. 2346, Sokoto, Nigeria

Phone: +2348034551260: Email: kabirhamid11@gmail.com 


\section{Introduction}

The knowledge of combining more than one plant material for the treatment of diseases have gain popularity in modern traditional medicine Page | 3990 (Subramani et al., 2014; Aslam et al., 2015) and preparation from this concept is referred as polyherbal formulation (PHF). Herbal formulation consist of different part of plant from different plants such as root, bark or leaves (Sulaiman et al., 2014). Some PHF exhibit immunomodulatory activity and therapeutic potentials especially in disease conditions such as immunosuppressed conditions (Gupta et al., 2006; Jawa et al., 2013). A substance that can specifically or nonspecifically stimulate immune system or induce secretion of several effector proteins such as complement, cytokines are referred as immunostimulatory agent (Choudary, 2012; Hajra et al., 2012). Whereas immunosuppressive agent weaken or regulate over reactive immune system. The issue of immunostimulation or suppression by herbal agent requires proper attention in order to maintain normal immune function (Vinothapooshan and Sundar, 2011). Several herbal formulation were not properly documented due to poor scientific data as well as poor standard regulation in preparation and marketing (Kazeem et al., 2013). This may risk the life of individuals due to adverse toxicity (Oshikoya et al., 2008). People consume locally prepare PHF without prior knowledge of its safety and undesirable effect it may cause on their immune cells (Olasunkanmi et al., 2017). The Polyherbal formulation called "Garjin®" locally was claimed to have anti-HIV, anti-microbial and immunomodulatory activities by local herbalist. Consequently, it is used by some local people. Although our previous study on the PHF indicated that it has potential immunostimulatory activity in animal model (Isah et al., 2018), none has indicated its effect on Macrophage function and humoral immune response against sheep red blood cells (SRBCs). Therefore, this study will offer scientific information on the immunomodulatory potential of aqueous PHF extract in mice targeting Macrophage phagocytic function and the humoral immune response against SRBCs. In addition, some medicinal plants have an effect on the phagocytic activity of Macrophages (Ranjith et al., 2015). Macrophages are group of immune cells found in tissues that recognise and kill microorganisms, abnormal or damaged cells, and any other foreign substances via phagocytosis and intracellular killing respectively (Davies et al., 2013). The process of taking in these substances is referred as phagocytosis (Ernst and Stendahl, 2006). The cells are indispensable in organism's biology because they play roles in homeostasis, body repair and development, as well as immune response to pathogens (Geissmann et al., 2010). Humoral immune response constitute a component of adaptive immune response and is responsible for synthesis of antibodies secreted by plasma cells which develop from B lymphocytes (Fuza and Skok, 2007, Hajra et al., 2012).

\section{Materials and Methods Polyherbal formulation}

Plant material was collected from Al-Mustakshif Medical Health Centre, Kano, Nigeria (RC: 1393615) then process as previously reported (Isah et al., 2018).The formulation consists of five plant materials namely: Black cutch- Bark (Acacia polyacentha wild), orchid bush-Bark (Bauhinia rufescens lam), Gum Arabic tree-Bark (Acacia Senegal), Boa boa leaves (Adensonia digitata), Garlic-Yellow-bulb (Allium sativum). The individual plant pharmacological potential was reported in our previous study (Isah et al., 2020). The plant taxonomic identification was carried out at the Herbarium section of Botany Unit, Department of Biological Sciences, Faculty of Sciences, Usmanu Danfodiyo University, Sokoto, Nigeria. The voucher numbers assigned are Adensonia digitata (UDUH/ANS/0194), Acacia senegal (UDUH/ANS/0195), Allium sativum (UDUH/ANS/0196), Bauhinia rufescens lam 
(UDUH/ANS/0197), Acacia polyacentha wild (UDUH/ANS/0198).

\section{The Polyherbal extract}

Department of Immunology, School of Medical Page | 3991 Laboratory Sciences supply the aqueous extract of the PHF. The extract was initially labelled as PHF aqueous extracts then stored and preserved at $5^{\circ} \mathrm{C}$ in airtight bottles. About $0.1 \mathrm{~g}$ of the dried extract was dissolved in $1 \mathrm{ml}$ of distilled water and this served as stock. The stock was prepared in batches (Hamid et al., 2021).

\section{Animals}

A total of 16 Mice of 8-12 weeks old, weight between 21-36 g of either sex (8 Females; 8 Males) were purchased from the Department of Veterinary Pharmacology, Faculty of Veterinary Medicine, Ahmadu Bello University (ABU), Zaria. Before the commencement of the experiment, the rats were allowed to acclimatize for two weeks, fed with standard food (Vital feed, Jos, Plateau) and water ad libitum in the animal house of Faculty of Pharmaceutical Sciences, Usmanu Danfodiyo University, Sokoto (UDUS). They were maintained under standard Laboratory conditions and the experimental protocol of the animal house was adapted. The study was approved by animal ethic committee of Department of Pharmacology and Toxicology, Faculty of Pharmaceutical Sciences, UDUS with approval number PTAC/PF/ (AE)/OT/14-19).

\section{Animal Grouping and Treatment}

After the acclimatization, the animals were divided randomly into four groups of four each. Group I serve as normal control, whereas other groups (IIIV) serve as treatment groups. Group I was given normal saline $10 \mathrm{ml} / \mathrm{kg}$ BW for 21 days. Group IIIV received different concentration (500, 1000, $1500 \mathrm{mg} / \mathrm{kg} \mathrm{BW}$ respectively) of the extract orally for 21 days.

\section{Phagocytic Function of Macrophage}

Carbon clearance assay was used to assess the effect of the polyherbal formulation treatment on the Macrophage as described by Yin et al., (2016). Indian ink (Camel brand) suspension was diluted in a ratio of 1:50 with normal saline and used for carbon clearance test in a dose of $0.1 \mathrm{ml} /$ mice. One hour after the last treatment, the animals were weighed then injected with $0.1 \mathrm{ml}$ of Indian ink via the tail vein and timed immediately. After the ink injection, at the time of $1 \mathrm{~min}$ (T1) and $15 \mathrm{~min}$ (T2). Blood samples were collected from orbital venous plexus using heparinized microhematocrit capillary tubes. The blood was immediately added with $3 \mathrm{ml}$ $0.1 \% \mathrm{Na}_{2} \mathrm{CO}_{3}$ solution to lyses the erythrocytes and the absorbance of the mixture was measured at 675 $\mathrm{nm}$ using spectrophotometer. The absorbance were A1 (at the time of T1) and A2 (at the time of T2), respectively, using the absorbance of $\mathrm{Na}_{2} \mathrm{CO}_{3}$ solution as a blank control. The mice were euthanatized under ketamine anaesthesia. Liver and spleen were exercised from the animal and were weighed immediately. The carbonic particle clearances index $(\mathrm{K})$ and Macrophage phagocytose index $(\alpha)$ as well as body weight index were calculated as below:

Carbonic particle clearances index $(K)=\underline{\log A 1-\log A 2}$ $\mathrm{T} 2-\mathrm{T} 1$

Macrophage phagocytose index $(\alpha)=\frac{\mathrm{K}^{1 /} \times \text { weight }}{\text { Liver }+ \text { spleen weight }}$ Index $(\mathrm{g} / 100 \mathrm{~g})=\frac{\text { Weight of spleen }}{\text { Body weight } \times 10}$

\section{Humoral Immune Response against SRBCs}

\section{Preparation of SRBCs (Antigen)}

The SRBCs was prepared as described by Dash et al., (2006). Briefly fresh blood of sheep was collected from local slaughterhouse in freshly prepared sterile Alsever's solution in a 1:1 ratio. Then centrifuged at $2000 \mathrm{rpm}$ for 10 minutes and washed with physiological saline 4-5 times. The cells were suspended in buffered saline and finally adjusted to a concentration of $1 \times 10^{8}$ cells $/ \mathrm{ml}$ for immunization and challenge. 


\section{Antibody response to $S R B C s$}

On the $14^{\text {th }}$ and $19^{\text {th }}$ day of the study, the mice from all the groups were sensitized and challenged, respectively, with SRBCs in normal saline $(0.1 \mathrm{ml}$ of suspension containing $1 \times 10^{8} \mathrm{SRBCs}$ ), intra-

Page | 3992 peritoneally. Blood was withdrawn (24 hours after the last dose) from the retro orbital plexus of all antigenically sensitized and challenged mice then centrifuged at $3000 \mathrm{rpm}$ for 5 minutes to obtain a serum.

\section{Direct Hemagglutination}

Briefly serum sample were incubated at $56^{\circ} \mathrm{C}$ for 30 min to inactivate the complement. Fifty microliters $(50 \mu 1)$ of Phosphate Buffered Saline (PBS) containing $0.05 \%$ Bovine Serum Albumin was dispensed into each well of round bottomed 96well microplate. Serum samples $(50 \mu \mathrm{l})$ were then added and serially double diluted in the wells from columns 2 to 12. The first column (PBS only) of wells was considered as blank. Then, $50 \mu \mathrm{l}$ of $1 \%$ SRBCs in PBS was added to all the wells to make a $100 \mu 1$ final volume. Subsequently, the plates were shaken for $1 \mathrm{~min}$ and incubated for 24 hours at $37^{\circ} \mathrm{C}$ and agglutination was monitored visually. Highest dilution capable of visible agglutination was considered as the antibody titre. A positive result was recorded when at least $50 \%$ SRBC agglutination was observed (Haghighi et al., 2005).

\section{Statistical Analysis}

The results obtained were entered into SPSS version 21 for analysis. Continuous variables were expressed as mean and standard deviation (SD) or Median. To ascertain the normal distribution of the variables Test for normality was carried out. Only Organ weight index was normally distributed based on tests of normality results: Shapiro-Wilk, complimented by Q-Q plot. Therefore ANOVA and Kruskal Wallis test were carried to compare mean or median respectively. Bonferroni and Mann Whitney tests were used as post hoc tests to compare some groups. The $p$ value $\leq 0.05$ was used to determine the level of statistical significance.
Results

Effect on carbonic particle clearance index Depicted from Table 1, there was statistically significant difference in carbonic particle clearances index (K) across the four groups after treatment with PHF ( $\mathrm{p}=0.02$ ) using Kruskal-Wallis test. The highest carbonic particle clearances index $(\mathrm{K})$ median score $(\mathrm{Md}=0.0228)$ was recorded in Group IV compare with other groups and the least was recorded in group I $(\mathrm{Md}=0.0006)$. MannWhitney U test (Post-hoc test) shows significant difference in carbonic particle clearances index $(\mathrm{K})$ between Group I and Group III, and Group I vs Group IV $(p=0.05)$. However, no significant difference between Group I and Group II ( $p=0.37)$.

\section{Effect on Macrophage Phagocytose Index}

There was statistically significant difference in Macrophage phagocytose index $(\alpha)$ across the four groups after treatment with PHF $(p=0.03$ ) using kruskal-Wallis test. The highest Macrophage phagocytose index $(\alpha)$ median score $(\mathrm{Md}=3.249)$ was recorded in Group IV compared to other groups and the least was recorded in group II $(\mathrm{Md}=1.009)$. Mann-Whitney $\mathrm{U}$ test (Post-hoc test) indicate that there is no significant difference in Macrophage phagocytose index $(\alpha)$ between group II-IV and control ( $p>0.05)$ (Table 1).

\section{Effect on organ weight index}

From Table 2, there was a statistically significant difference in organ weight index across the different groups $(p<0.0001)$ using ANOVA. The highest organ weight index $(\mathrm{g} / 100 \mathrm{~g})$ mean score $(\mathrm{M}=0.06633)$ was recorded by Group IV compared with other groups and the least was recorded by group II (Mean=0.00043). Bonferroni test (Post-hoc test) shows statistically significant difference in organ Weight index between group I and group IV $(\mathrm{p}<0.0001)$. However, no statistically significant difference was recorded when group I was compared with group II and III $(\mathrm{p}>0.05)$. 
Effect on humoral immune response against SRBCS

As shown in Table 3, There was statistically significant difference in HA titre across the four groups after treatment with PHF $(\mathrm{p}=0.02)$ using kruskal-Wallis test. The highest HA titre median score $(\mathrm{Md}=32.00)$ was recorded by Group IV when compared with other groups, followed by group III $(\mathrm{Md}=16.00)$ and group I $(\mathrm{Md}=4.00)$ recorded the least. Mann-Whitney U test (Posthoc test) shows significant difference in HA titre between group I and group IV $(p=0.04)$. However, there was no statistical significant difference when compared with other groups $(\mathrm{p}>0.05)$.

Table 1: Effect of aqueous extract of PHF on Carbonic particle clearances index (K) and Macrophage phagocytose index $(\alpha)$ in Mice

\begin{tabular}{cccccc}
\hline Group (N=16) & Dose $(\mathbf{k g ~ B W})$ & \multicolumn{2}{c}{ K } & \multicolumn{2}{c}{$\boldsymbol{\alpha}$} \\
\cline { 2 - 5 } & & Median & p-value & Median & p-value \\
\hline I (NS) & $10 \mathrm{ml}$ & 0.0006 & 0.02 & 1.345 & 0.03 \\
II (PHF) & $500 \mathrm{mg}$ & 0.0010 & & 1.009 & \\
III (PHF) & $1000 \mathrm{mg}$ & $0.0014^{\mathrm{a}^{*}}$ & & 1.449 & \\
IV (PHF) & $1500 \mathrm{mg}$ & $0.0228^{\mathrm{b}^{*}}$ & & 3.249 & \\
\hline
\end{tabular}

$\mathrm{N}=$ total number of rats, NS= Normal Saline; $\mathrm{PHF}=$ Polyherbal Formulation, a= I vs III, $b=\mathrm{I}$ vs IV, $\mathrm{p}=0.05$

Table 2: Effect of aqueous extract of PHF on organ weight Index $(\mathrm{g} / 100 \mathrm{~g})$ in Mice

\section{Group (N=16) Dose (kg BW) Organ weight Index (g/100g)}

\begin{tabular}{cccc}
\cline { 3 - 4 } & & \multicolumn{1}{c}{ Mean (SD) } & p-value \\
\hline I (NS) & $10 \mathrm{ml}$ & $0.00066(0.00005)$ & $<0.0001$ \\
II (PHF) & $500 \mathrm{mg}$ & $0.00043(0.00049)$ & \\
III (PHF) & $1000 \mathrm{mg}$ & $0.00116(0.00037)$ & \\
IV (PHF) & $1500 \mathrm{mg}$ & $0.06633(0.00740)^{\mathrm{a}^{* * *}}$ & \\
\hline
\end{tabular}

$\mathrm{N}=$ total number of rats, $\mathrm{a}=\mathrm{I}$ vs IV,${ }^{* * * *} \mathrm{p}<0.0001$

Table 3: Effect of aqueous extract of PHF on humoral immune response against SRBCs in mice

Group (N=16) Dose (kg BW) HA Median Titre p-value

\begin{tabular}{cccc}
\hline I (NS) & $10 \mathrm{ml}$ & 4.00 & 0.02 \\
II (PHF) & $500 \mathrm{mg}$ & 8.00 & \\
III (PHF) & $1000 \mathrm{mg}$ & 16.00 & \\
IV (PHF) & $1500 \mathrm{mg}$ & $32.00^{\mathrm{a}^{*}}$ & \\
\hline
\end{tabular}

$\mathrm{N}=$ total number of rats, $\mathrm{a}=\mathrm{I}$ vs IV, ${ }^{*} \mathrm{p}=0.04$

\section{Discussion}

Polyherbal formulations are getting more attention in treatment of different disease conditions (Sushruta et al., 2007). Stimulation or suppression of immune system are important parameters to rely on for assessment of normal function of the system (Bagwan et al., 2017). Ascertaining the local herbalist's claims on PHF ability to modulate immune system will lead to discovery of novel drug that could be reliable in curing or alleviating disease conditions (Majeedi et al., 2015). 
Our study demonstrated significant increase in carbon clearance as well as phagocytic ability of Macrophages in response to dose increase of the formulation. This study findings suggest potential immunostimulatory activity on Macrophage

Page | 3994 function as one of the key player in innate immune response. Because Macrophages are responsible for the innate immunity that contribute to the clearance of foreign bodies by recognition and migration toward the foreign bodies, phagocytosis, and destruction of foreign agents (Gokhale et al., 2003). Similarly the result of the present study shows significant increase in organ weight index with increase in dose. Several studies (Ismail and Asad, 2009), (Patel and Asdaq, 2010), (Tilwari et al., 2011), (Hajra et al., 2012), (Anerthe et al., 2014), (Jitin et al., 2015) reported significant increase in Macrophage phagocytic function. In contrary the ethanolic root extract of Argyreia speciosa was reported effective on Macrophage phagocytosis (Gokhale et al., 2003). Daniel recorded a significant raise in relative organ weight in rats after treatment with aqueous extract of Pseudocedrela kotschyi (Daniel, 2018). Olayode and colleagues reported significant increases in relative organ weight after treatment with leaf extract of Stachytarpheta cayennensis in rats (Olayode et al., 2019). Porwal and co-workers reported no significant changes in organ weight after treatment of rats with Ethanolic Extract of Marsdenia tenacissima leaves (Porwal et al., 2017).

The carbon clearance assay shows the rate at which carbon particle were removed from blood after systemic injection of carbon particle in form of ink and the rate of the clearance was deduce as reported (Gokhale et al., 2003). The removal of carbon particles was made by phagocytic cells such as Macrophages. The phagocytic index as well as Macrophage activity was assessed by the assay (Ponkshe and Indap, 2002). Defect in phagocytic process may lead to several disease conditions in humans (White and Gallin, 1986). Because Macrophages are very important in secretion of several cytokines which ultimately lead to the activation of immune cells (Tilwari et al., 2011).

The result on humoral immune response against SRBCs antigen reveals that there is significant increase in humoral immune responses in a dose dependant manner, suggesting treatment with the formulation may have the ability to activate lymphocytes especially the B lymphocytes and other cells associated with humoral immune response. Antibodies are produce by plasma cells upon interaction between B lymphocytes and antigen thus lead to its proliferation and differentiation into the antibody secretion cells. The antibodies produce were set to bind to the antigen and neutralised or facilitate recognition by phagocytes this lead to ultimate elimination of the antigen (Gokhale et al, 2003, Fulzele et al., 2003). Several studies reported significant increase in circulating antibodies after treatment with different plant extract, Argyreia speciosa root (Gokhale et al., 2003), Acacia polyacentha wild (Ismail and Asad, 2009), Aegle marmelos (Patel and Asdaq, 2010), Swietenia mahagoni (Hajra et al., 2012) and Adensonia digitata (Jitin et al., 2015), and Some extracts especially at a higher doses showed more immunostimulating effects (Tatfeng and Emitan, 2012). However, Tilwari and co-workers reported inhibitory effect on humoral immune response in mice after treatment with Abrus precatorius (Tilwari et al., 2011). The difference may be attributed to suppression of functional activity of antigen presenting cells or type as well as level of cytokines present at the microenvironment after activation of lymphocytes (Allison, 2000).

\section{Conclusions}

The formulation increase the Macrophage phagocytic function and humoral immune response against SRBCs antigen in mice. Therefore, it has ability to stimulate reticuloendothelial system and lymphocytes 
associated with humoral immune response. It could be used as potential immunomodulatory formulation after an in-depth research.

\section{Acknowledgement}

Page | 3995 The authors appreciate the co-operation of Mr. Sani Muhammad Umar (Nagge) of Al-Mustakshif Medical Health Centre, Kano, Nigeria (RC: 1393615) for the $\operatorname{Garjin}{ }^{\circledR}$ PHF. We also appreciate the effort of Mr. Abdullahi Suleiman, Mr. Abdulrasheed Ahmad and Mr. Salmanu Makama from Faculty of Pharmaceutical Science, Usmanu Danfodiyo University, Sokoto, Nigeria for the sample collection.

\section{Competing interests}

The authors declare that there is no conflict of interests regarding the publication of this paper.

\section{References}

Allison, A.C. (2000). Immunosuppressive drugs: the first 50 years and a glance forward. Immunopharmacology. 47:63-83

Anarthe, S.J., Sunitha, D., Sandhya, R., Raju, M.G. (2014). Immunomodulatory activity of Methanolic Extract of Trigonella Foenum Graeceum whole plant in Wistar Albino Rats. American Journal of Phytomedicine and Clinical Therapeutics. 2(9): 1081-1092.

Aslam, M. S., Ahmad, M. S., Mamat, A. S., Ahmad, M. Z., Salam, F. (2016). An Update Review on Polyherbal Formulation: A Global Perspective. Systematic Reviews in Pharmacy. 7(1): 35-41.

Bagwan, S.A., Naikwade, N.A., Manure, J.Y. (2017). Comparative study of Immunomodulatory activity of marked Ayurvedic formulation. Indo American Journal of Pharmaceutical Sciences. 4(2): 4776-4782.
Choudhary, G.P. (2012). Immunomodulatory activity of alcoholic extract of Termina liabelerica in mice. The Pharma Letter. 4(2): 414-417.

Daniel, A. (2018). Effects of Pseudocedrela kotschyi stem bark on blood chemistry and histology of some organs in rats. Journal of Clinical and Experimental Toxicology. 2(2):1-7.

Dash, S., Nath, L.K., Bhisem S., Kar, P., Bhattacharya, S. (2006). Stimulation of immune function activity by the alcoholic root extract of Heracleum nepalense D. Don. Indian Journal of Pharmacology. 38: 336-340.

Davies, L., Jenkins, S., Allen, J., Philip, R. T. (2013). Tissue-resident Macrophages. Nature Immunology. 14: 986-995.

Ernst, J.D., Stendahl, O. (2006). Phagocytosis of Bacteria and Bacterial Pathogenicity. 1st ed. Cambridge University Press.

Fulzele, S.V., Satturwar, P.M., Joshi, S.B., Dorle, A.K. (2003). Study of the immunomodulatory activity of Haridradi ghrita in rats. Indian Journal of Pharmacology. 35:51-54.

Fuza, M., Skok, J.A. (2007). Transcriptional regulation in early B-cells development. Current Opinion in Immunology. 19(2), 129-136.

Geissmann, F., Manz, M.G., Jung, S., Sieweke, M.H., Merad, M., Ley, K. (2010). Development of monocytes, Macrophages, and dendritic cells. Science. 327(5966):656-661.

Gokhale, A.B., Damre, A.S., Saraf, M.N. (2003). Investigations into the immunomodulatory 
activity of Argyreia speciosa. Journal of Ethnopharmacology. 84: 109-114.

Gupta, M.S., Shivaparasad, H.N., Kharya, M.D., Rana, A.C. (2006). Immunomodulatory Page | 3996 Activity of the Ayurvedic Formulation "Ashwaghandha Churna". Pharmaceutical Biology. 44(4): 263-273.

Haghighi, H.R., Gong, J., Carlton, L., Gyles, M., Hayes, A., Sanei, B., Parvizi, P., Haris, Gisavi., James, R.C., Shayan, S. (2005). Modulation of Antibody-Mediated Immune Response by Probiotics in Chickens. Clinical and diagnostic laboratory immunology. 12(12): 1387-1392.

Hajra, S., Archana, M., Pinkee, P. (2012). Immunostimulating Activity of Methanolic Extract of Swietenia Mahogani seeds. International Journal of Pharmacy and Pharmaceutical Sciences. 4(1): 442-445.

Hamid, K.M., Isah, S.Y., Kalgo, M.U., Isiyaku, A., Usman, A.B., Yeldu, M.H., Yusuf, A., Abubakar, N.K., Garba, Y.B., Muhammad, H.Y. (2021). Immunostimulatory Activity of Aqueous Extract of Polyherbal Formulation on Th1/Th2 Cytokines Secretion and Cell Mediated Immune Response in Rats. Saudi Journal of Medical and Pharmaceutical Sciences, 7(1): 64-70.

Isah, S.Y., Mohammed, H.Y., Hamid, K.M., Usman, M., Mustapha, U.K. (2018). Effect of Polyherbal Formulation on Neutrophil function and TDAR in Wistar albino rat. European Journal of Pharmaceutical and Medical Research. 5(12), 563-568.

Isah, S. Y., Hamid, K. M., Muhammad, H. Y., Garba, Y. B., Yusuf, A., Abubakar, U. (2020). Phytochemical Screening, Acute Toxicity Study and Immunomodulatory activity of aqueous extract of Polyherbal Formulation in albino Wistar Rats. World
Journal of Pharmaceutical Research, 9(8):165-177.

Ismail, S., Asad, M. (2009). Immunomodulatory activity of Acacia Catechu. The Indian Journal of Physiology and Pharmacology. 53(1): 25-33.

Jawa, V., Cousens, L.P., Awwad, M., Wakshull, E., Kropshofer, H., De Groot, A.S. (2013). T-cell dependent immunogenicity of protein therapeutics: Preclinical assessment and mitigation. Clinical Immunology. 149(3):534-555.

Jitin, R., Manish, K.J., Shishu, P.S., Rakesh, K.K., Anuradha, I., Aliya, N., Anup, K.G., Sujeet, K.M. (2015). Adansonia digitata L. (baobab): a review of traditional information and taxonomic description. Asian Pacific Journal of Tropical Biomedicine. 5(1): 79-84.

Majeedi, S.F., Roquiya, M., Johan, O., Khan, A.A. (2005). Immunomodulating herbs of umani medicine: A review. International Journal of Herbal Medicine. 3(4): 19-21.

Olasunkanmi, O.O., Akinpelu, D.A,, Adeniyi, P.O,, Ajayi, O.F, Omololu-Aso, J., Olorunmola, F.O. (2017). Investigations into Antibacterial, Phytochemical and Antioxidant Properties of Vitellaria paradoxa (Gaertn.) Stem Bark Extracts. International Journal of Pharmaceutical Sciences and Research. 20(5): 1-17.

Olayode, O.A., Daniyan, M.O., Olayiwola, G. (2020). Biochemical, hematological and histopathological evaluation of the toxicity potential of the leaf extract of Stachytarpheta cayennensis in rats. Journal of Traditional and Complementary Medicine. 10(6): 544-554.

Oshikoya, K.A., Oreagba, I.A., Ogunleye, O.O., Oluwa, R., Senbanjo, I.O., Olayemi, S.O. 
(2013). Herbal medicines supplied by community pharmacies in Lagos, Nigeria: pharmacists' knowledge. Pharmacy Practice. 11(4):219-227.

Page | 3997 Oshikoya, K.A., Senbanjo, I.O., Njokanma, O.F., Soipe, A. (2008). Use of complementary and alternative medicines for children with chronic health conditions in Lagos, Nigeria. BMC Complementary and Alternative Medicine. 8:66.

Parasuraman, S., Thing, G. S., Dhanaraj, S. A. (2014). Polyherbal formulation: concept of Ayurveda. Pharmacognosy reviews. 8(16): $73-80$

Patel, P., Asdaq, M.B. (2010). Immunomodulatory activity of methanolic fruit extract of Aegle marmelos in experimental animals. Saudi Pharmaceutical Journal. 18: 161-165.

Ponkshe, C.A., Indap, M.M. (2002). In vivo and in vitro evaluation for immunomodulatory activity of three marine animal extracts with reference to phagocytosis. Indian Journal of Experimental Biology. 40:1399-1402.

Porwal, M., Khan, N.A., Maheshwari, K.K. (2017). Evaluation of Acute and Subacute Oral Toxicity Induced by Ethanolic Extract of Marsdenia tenacissima Leaves in Experimental Rats. Scientia Pharmaceutica. 85(29): 1-11.

Ranjith, M.S., Ranjitsingh, A.J.A., Gokul, S.S., Vijayalaksmi, G.S., Deepa, K., Sidhu, H.S. (2008). Enhanced Phagocytosis and Antibody Production by Tinospora cordifolia - A new dimension in Immunomodulation. African Journal of Biotechnology. 7 (2):081-085.

Shushruta, K., Satyanarayana, S., Srinivas, S., Sekhar, J.R. (2007). Evaluation of blood glucose reducing effect of aqueous extract of the Umbelliferous fruit used in culinary practice. Tropical Journal of Pharmaceutical Research. 5(2): 613-617.

Sulaimana, F.A., Kazeem, M.O., Waheeda, A.M., Temowoa, S.O., Azeeza, I.O., Zubair, F.I., Adeyemi, T.A., Nyang, A., Adeyemi, O.S. (2014). Antimicrobial and toxic potential of aqueous extracts of Allium sativum, Hibiscus sabdariffa and Zingiber officinale in Wistar rats. Journal of Taibah University for Science. 8(4): 315-322.

Tafteng, Y.M., Enitan, S.S. (2012). Effect of Allium Cepa and Allium Sativum on some immunological cells in Rats. African Journal of Traditional, Complementary and Alternative Medicines. 9(3): 374-379.

Tilwari, A., Shukla, N.P., Pathirissery, U.D. (2011). Immunomodulatory Activity of the Aqueous Extract of Seeds of Abrus precatorius Linn (Jequirity) in Mice. Iran. Journal of Immunology. 8(2):96-103.

Vinothaposhan, G., Sundar, K. (2011). Immunomodulatory activity of various extracts of Adhatoda vasica Linn, in experimental Rats. African Journal of. Pharmacy and Pharmacology. 5(3): 306310.

White, C.J., Gallin, J.I. (1986). Phagocyte defects. Journal of Clinical Immunology. 40: 50-61.

Yin, J.J., Zhou, Q., Wang, L., Xu, W., Zhang, J.L. (2016). Protective effect of extract of Mauremys mutica against cyclophosphamide (CY)-induced suppression of immune function in mice. Food and Agricultural Immunology. 27(4): 577-588 